\title{
Growth, Yield, and Fruit Quality of Eight Lemon Cultivars in Arizona
}

\author{
Esmaeil Fallahi, D. Ross Rodney, and Zahra Mousavi \\ Yuma Agricultural Center, University of Arizona, Rt. 1, Box 40-M, Somerton, AZ 85350 \\ Additional index words. Citrus limon
}

\begin{abstract}
Tree growth, yield, and fruit quality of eight lemon cultivars [Citrus limon (L.) Burro. f.] on macrophylla (Alemow) (C. macrophylla Wester) rootstock were compared when grown in sandy soil in the arid climate of southwestern Arizona. 'Foothill Lisbon' had higher cumulative yield and titratable acids than 'Monroe Lisbon', 'Prior Lisbon', 'Eureka', and 'Villafranca', and had larger fruit than other 'Lisbon' cultivars. 'Prior Lisbon' produced a larger tree canopy with lower yield efficiency than all other cultivars and did not show any decline due to sieve tube necrosis 12 years after planting. Overall, 'Eureka' cultivars and'Villafranca' had lower relative cumulative yields, canopy volumes, total soluble solids content, titratable acids, and seed content, but higher tree decline than 'Lisbon' cultivars. Overall, 'Foothill Lisbon', in spite of carrying exocortis viroid, produced good yields and fruit quality and 'Prior Lisbon' had a satisfactory growth-performance.
\end{abstract}

Previous studies with lemon cultivars have focused on general fruit description (Hodgson, 1967), tree decline (Allen et al., 1976, 1977, 1982; Platt et al., 1972), or on total soluble solids (TSS) and percentage of titratable acid (TA) of the juice (Sinclair and Eny, 1945; Batchelor and Bitters, 1954). Sinclair and Eny (1945) reported that 'Lisbon' had higher TSS and TA than 'Eureka'. Soni and Randhawa (1969) reported a higher TSS and TA in 'Columbia' than in 'Hill'. Rouse and Knorr (1970) compared four lemon cultivars for their rind, pulp, juice, and seed content. They found that 'Italian' had a higher percent juice and pulp, but lower percent rind than 'Villafranca', 'Nucellar Bearss', and 'Bearss \# 1'. Batchelor and Bitters (1954) compared storability and juice production of 'Prior Lisbon', 'Rosenberger Lisbon', 'Monroe Lisbon', 'C.E.S. Villafranca', 'Allen Eureka', and 'Frost Eureka' and reported that 'Lisbon' cultivars had the highest TA, while 'C.E.S. Villafranca' had the lowest of all those tested. In their study, 'Frost Eureka' had the highest amount of juice per tonne of fruit before and after storage (Batchelor and Bitters, 1954).

Lemon is the major type of citrus produced in southwestern Arizona, where annual production is $=175,000 \mathrm{t}$, which constitutes $25 \%$ of the total lemon production in the United States (Arizona Agricultural Statistics, 1987). Despite this large production, there have been no comprehensive long-term studies in Arizona comparing growth, yield, and fruit quality of various cultivars of lemons. High yield, large fruit size, high percentage of packout, high juice and acid content, and thin rind are desirable characteristics in commercial lemon production. Lemons with fewer seeds are also desirable for the fresh market and home gardening. Our objective was to compare growth, yield, and quality characteristics under the arid climate of southwestern Arizona for selections (cultivars) representative of the three major lemon cultivars: 'Lisbon', 'Eureka', and 'Villafranca'.

\section{Materials and Methods}

Trees were budded onto macrophylla rootstock because of its moderate resistance to phytophthora and precocity of scions budded onto it. Seeds were collected from a virus-free macrophylla tree and planted in the greenhouse. The seedlings were

Received for publication 15 July 1988. Arizona Agricultural experiment Station Technical Paper 6004. The cost of publishing this paper was defrayed in part by the payment of page charges. Under postal regulations, this paper therefore must be hereby marked advertisement solely to indicate this fact. grown and budded in the greenhouse with eight cultivars: 'Foothill Lisbon', 'Frost Nucellar Lisbon' ('F.N. Lisbon'), 'Monroe Lisbon', 'Prior Lisbon', 'Rosenberger Lisbon', 'Frost Nucellar Eureka' ('F. N. Eureka'), 'Cook Eureka', and standard 'Villafranca'. All cultivars were virus-free except 'Foothill Lisbon' and 'Monroe Lisbon', which carried exocortis. At the time of planting, no exocortis-free 'Foothill Lisbon' or 'Monroe Lisbon' bud sources were available.

The orchard was established at the Univ. of Arizona Yuma Mesa Agricultural Center in southwestern Arizona in May 1970. The experimental design was a randomized complete block with six blocks (replications) of two trees each (total of 12 trees per cultivar), with guard trees on the end of each row. Planting distance was $8.5 \times 9.1 \mathrm{~m}$. The soil was a Superstition sand (Typic Calciorthid, sandy, mixed, hyperthermic; $85 \%$ sand) and soil $\mathrm{pH}$ was 8.0. The trees were flood irrigated twice each month during April through September and monthly during October through March. Ammonium nitrate was applied in five equal applications in October, December, February, March, and April every year at the total annual rate of 0.5 to $1.5 \mathrm{~kg} \mathrm{~N} /$ tree, depending on the age of trees. Pesticide was applied twice annually for thrip control and the orchard was disked for weed control as needed. Overall, cultural practices, soil, and other environmental conditions in this experimental block were similar to those of commercial blocks in southwestern Arizona, where mean annual precipitation in $=63.5 \mathrm{~mm}$.

Yield and trunk circumference ( $=15 \mathrm{~cm}$ above the bud union) were measured and trunk cross sectional area was calculated annually and cumulative yield was calculated for 7 years from 1976 through 1982. The canopy volume was measured in Mar. 1982 (12 years after planting). To measure tree volume, tree shape was assumed to be one-half of a prolate spheroid (Turrell, 1961; Serfontein and Catling, 1968; Jahn, 1979; Morse et al., 1987); thus, volume is calculated by the equation: $\mathrm{V}=0.524$ $\mathrm{x}$ height $\mathrm{x}$ width ${ }^{2}$. This method is a modified form of a formula that was originally used by Turrell (1946) to calculate the volume of fruit with a prolate spheroid shape. Yield efficiency for 1982 was calculated as the ratio of 1982 yield to tree volume in 1982. Cumulative yield efficiency was calculated as the ratio of cumulative yield to tree volume in 1982. The number of trees affected by sieve tube necrosis decline was counted in 1982 (12 years after planting). Criteria used for decline in this experiment were similar to those of macrophylla sieve tube necrosis as described by Platt et al. (1972) and Allen et al. (1982).

Fruit weight, juice volume, percent juice content, TSS, TA, 
Table 1. Yield, yield efficiency, and growth of various cultivars of lemon in Arizona. $z, y$

\begin{tabular}{lcccccc}
\hline \hline & $\begin{array}{c}\text { Cumulative } \\
\text { yield, } \\
1976-82 \\
(\mathrm{~kg} / \mathrm{tree})\end{array}$ & $\begin{array}{c}\text { Trunk } \\
\text { cross-sectional } \\
\text { area, 1982 } \\
\left(\mathrm{cm}^{2}\right)\end{array}$ & $\begin{array}{c}\text { Canopy } \\
\text { vol., 1982 } \\
\left(\mathrm{m}^{3}\right)\end{array}$ & $\begin{array}{c}\text { Cumulative } \\
\text { yield } \\
\text { efficiency } \\
\left(\mathrm{kg} \cdot \mathrm{m}^{-3}\right)\end{array}$ & $\begin{array}{c}\text { 1982 yield } \\
\text { efficiency } \\
\left(\mathrm{kg} \cdot \mathrm{m}^{-3}\right)\end{array}$ & $\begin{array}{c}\text { Trees with } \\
\text { decline } \\
\text { by } 1982 \\
(\%)\end{array}$ \\
\hline Foltivar & $601 \mathrm{a}$ & $282 \mathrm{ab}$ & $41.9 \mathrm{~b}$ & $14.3 \mathrm{a}$ & $1.86 \mathrm{~b}$ & 25 \\
F.N. Lisbon & $559 \mathrm{ab}$ & $272 \mathrm{abc}$ & $39.2 \mathrm{bc}$ & $14.2 \mathrm{a}$ & $2.04 \mathrm{ab}$ & 25 \\
Mo. Lisbon & $451 \mathrm{bc}$ & $198 \mathrm{~d}$ & $29.8 \mathrm{c}$ & $15.1 \mathrm{a}$ & $1.44 \mathrm{~b}$ & 25 \\
Pr. Lisbon & $446 \mathrm{bc}$ & $292 \mathrm{ab}$ & $57.3 \mathrm{a}$ & $7.8 \mathrm{~b}$ & $1.06 \mathrm{c}$ & 0 \\
Ro. Lisbon & $527 \mathrm{ab}$ & $226 \mathrm{~cd}$ & $37.5 \mathrm{bc}$ & $14.1 \mathrm{a}$ & $1.79 \mathrm{~b}$ & 8 \\
F.N. Eureka & $429 \mathrm{bc}$ & $266 \mathrm{bc}$ & $29.2 \mathrm{c}$ & $14.7 \mathrm{a}$ & $2.63 \mathrm{a}$ & 42 \\
Co. Eureka & $406 \mathrm{c}$ & $321 \mathrm{a}$ & $29.6 \mathrm{c}$ & $13.7 \mathrm{a}$ & $2.70 \mathrm{a}$ & 42 \\
Vi.franca & $388 \mathrm{c}$ & $227 \mathrm{~cd}$ & $27.4 \mathrm{c}$ & $14.1 \mathrm{a}$ & $2.33 \mathrm{a}$ & 75 \\
\hline
\end{tabular}

zTrunk cross-sectional area measured 12 years after planting; yield efficiency $=$ yield/volume. Canopy volume is for each tree measured 12 years after planting.

yMean separation within columns by Duncan's multiple range test, $P=0.05$.

'Fo. Lisbon = 'Foothill Lisbon'; F.N. Lisbon = 'Frost Nucellar Lisbon'; Mo. Lisbon = 'Monroe Lisbon'; Pr. Lisbon = 'Prior Lisbon'; Ro. Lisbon = 'Rosenberger Lisbon'; F.N. Eureka = 'Frost Nucellar Eureka'; Co. Eureka = 'Cook Eureka'; Vi.franca = 'Villafranca'.

Table 2. Influence of various cultivars on lemon fruit quality..$^{\mathbf{z} y}$

\begin{tabular}{lcllllll}
\hline \hline & $\begin{array}{c}\text { Fruit wt. } \\
(\mathrm{g})\end{array}$ & $\begin{array}{c}\text { Juice vol. } \\
(\mathrm{ml} / \mathrm{fruit})\end{array}$ & $\begin{array}{c}\text { Percent } \\
\text { juice } \\
(\mathrm{w} / \mathrm{w})\end{array}$ & $\begin{array}{c}\text { Rind } \\
\text { thickness } \\
(\mathrm{mm})\end{array}$ & $\begin{array}{c}\text { Total } \\
\text { soluble } \\
\text { solids } \\
\text { ('Brix) }\end{array}$ & $\begin{array}{c}\text { Titratable } \\
\text { acid } \\
\text { (\% juice) }\end{array}$ & $\begin{array}{c}\text { Seeds } \\
\text { (avg./fruit) }\end{array}$ \\
\hline Fo. Lisbon & $105.4 \mathrm{a}^{\mathrm{x}}$ & $42.6 \mathrm{ab}$ & $41.4 \mathrm{a}$ & $3.9 \mathrm{ab}$ & $7.66 \mathrm{a}$ & $5.4 \mathrm{a}$ & $6 \mathrm{bc}$ \\
F.N. Lisbon & $97.5 \mathrm{~b}$ & $41.3 \mathrm{abc}$ & $43.4 \mathrm{a}$ & $3.6 \mathrm{~b}$ & $7.61 \mathrm{a}$ & $5.3 \mathrm{ab}$ & $4 \mathrm{~cd}$ \\
Mo. Lisbon & $97.0 \mathrm{~b}$ & $39.9 \mathrm{bc}$ & $42.2 \mathrm{a}$ & $3.8 \mathrm{ab}$ & $7.60 \mathrm{a}$ & $5.2 \mathrm{~b}$ & $8 \mathrm{ab}$ \\
Pr. Lisbon & $95.3 \mathrm{~b}$ & $39.1 \mathrm{c}$ & $41.8 \mathrm{a}$ & $3.5 \mathrm{~b}$ & $7.54 \mathrm{ab}$ & $5.2 \mathrm{~b}$ & $7 \mathrm{ab}$ \\
Ro. Lisbon & $97.6 \mathrm{~b}$ & $40.0 \mathrm{bc}$ & $41.9 \mathrm{a}$ & $3.8 \mathrm{ab}$ & $7.55 \mathrm{ab}$ & $5.3 \mathrm{ab}$ & $9 \mathrm{a}$ \\
F.N. Eureka & $105.5 \mathrm{a}$ & $44.4 \mathrm{a}$ & $43.1 \mathrm{a}$ & $3.8 \mathrm{ab}$ & $7.33 \mathrm{~cd}$ & $4.9 \mathrm{c}$ & $2 \mathrm{~d}$ \\
Co. Eureka & $106.5 \mathrm{a}$ & $41.6 \mathrm{ab}$ & $40.5 \mathrm{a}$ & $4.1 \mathrm{a}$ & $7.26 \mathrm{~d}$ & $4.8 \mathrm{c}$ & $3 \mathrm{~d}$ \\
Vi.franca & $104.2 \mathrm{a}$ & $43.7 \mathrm{a}$ & $43.0 \mathrm{a}$ & $3.8 \mathrm{ab}$ & $7.41 \mathrm{bc}$ & $4.9 \mathrm{c}$ & $4 \mathrm{~cd}$ \\
\hline
\end{tabular}

${ }^{2}$ Each value in the table represents an average of 7 years of data with six blocks (replications) per cultivar, two trees per replication, and 10 fruit/tree.

'Mean separation within columns by Duncan's multiple range test, $P=0.05$.

×Fo. Lisbon = 'Foothill Lisbon'; F.N. Lisbon = 'Frost Nucellar Lisbon'; Mo. Lisbon = 'Monroe

Lisbon'; Pr. Lisbon = 'Prior Lisbon'; Ro. Lisbon = 'Rosenberger Lisbon'; F.N. Eureka =

'Frost Nucellar Eureka'; Co. Eureka = 'Cook Eureka'; Vi.franca = 'Villafranca'.

rind thickness, and seed content were evaluated annually for 7 years. Ten fruit per tree were collected randomly in early December of each year. Fruit were weighed, cut in half, and seeds counted. Rind thickness was measured using a digital caliper. Juice was extracted and total juice volume per fruit was measured in a graduated cylinder. A 500-ml aliquot of each composite juice sample was weighed, and the specific gravity was calculated from weight to volume measurements. TSS was measured with a temperature compensated refractometer (Atago N1). Titratable acid was determined by titration with $0.39 \mathrm{~N} \mathrm{NaOH}$ to a $\mathrm{pH}$ of 8.0, using an automated Fisher Titralizer (Fisher Scientific Co. Model 41) and TA was determined on a citric acid basis. Analyses of variance for cumulative yield over 7 years, tree canopy volume and yield efficiency for 1982 and cumulative yield efficiency over 7 years, and analyses of variance for 7-year averages for each quality factor are reported.

\section{Results and Discussion}

Yield and growth. 'Lisbon' cultivars, particularly 'Foothill', tended to yield more than 'Eureka' cultivars and 'Villafranca', perhaps because the 'Lisbon' trees had larger canopies (Table 1). The larger canopy volume of 'Lisbon' as compared to 'Eureka' cultivars is in agreement with Hodgson (1967). 'F.N. Eureka', 'Rosenberger Lisbon', 'Prior Lisbon', 'Monroe Lisbon', and 'F.N. Lisbon' had similar cumulative yields. These results differ from those of Goodall and Bitters (1958), where 'Prior Lisbon' had significantly lower cumulative yield than 'Monroe Lisbon', 'F.N. Lisbon', and 'F.N. Eureka' in the coastal areas of California. However, 'Prior Lisbon' had significantly lower cumulative yield efficiency and 1982 yield efficiency than all other cultivars due to its large tree canopy (Table 1).

'Cook Eureka' had significantly larger trunk cross-sectional area than 'Monroe Lisbon', 'Rosenberger Lisbon', 'F.N. Eureka', and 'Villafranca'. No difference was found in the cross-sectional areas of 'Cook Eureka', 'F.N. Lisbon', 'Foothill Lisbon', and 'Prior Lisbon'. Nevertheless, 'Prior Lisbon' had a significantly larger canopy volume than all other cultivars due to the lack of sieve tube necrosis decline (Table 1). Thus, cross-sectional area was not necessarily proportional to canopy volume in all cultivars (Table 1) and, therefore, reporting yield efficiency as yield per canopy volume is a better approach than using yield per trunk cross-sec- 
tional area. Tree volume calculated in this experiment is in general agreement with Turrell et al. (1961).

'Prior Lisbon' trees did not show any signs of sieve tube necrosis decline in our experiment (Table 1) or in the 12-yearold commercial groves. These findings are in agreement with those of Platt et al. (1972), but differ from those of Allen et al. (1977). We evaluated the tree decline 12 years after planting, while Allen et al. (1977) evaluated for decline when trees were 17 years old. Visual symptoms of decline in our experiment became more evident in 'Prior Lisbon' and 'Rosenberger Lisbon' in 1988 (18 years after planting). Decline symptoms were more severe in 'Villafranca' and 'Eureka' cultivars than in the others (Table 1). This result is in agreement with that of Platt et al. (1972) and Allen et al. (1977, 1982).

Fruit quality. 'Foothill Lisbon', cultivars of 'Eureka', and 'Villafranca' had larger and relatively juicier fruit than other 'Lisbon' cultivars (Table 2). Although 'Foothill Lisbon' had heavier fruit than 'Monroe Lisbon', 'F.N. Lisbon', and 'Rosenberger Lisbon', all of these cultivars had a similar juice volume per fruit (Table 2). The rind of 'Cook Eureka' was significantly thicker than those of 'F.N. Lisbon' and 'Prior Lisbon' (Table 2), while no difference was observed in the rind thickness of these three cultivars in the coastal range of California (Goodall and Bitter, 1958). No differences were found in the percent juice content (w/w) among cultivars, because most of the cultivars that had large fruit with high juice content also had thicker rinds (Table 2). This result differs from that of Batchelor and Bitters (1954) in California, where 'Villafranca' had a lower percentage of juice than 'Eureka' and 'Lisbon' cultivars. 'Lisbon' cultivars generally had a higher TSS and TA than 'Villafranca' and 'Eureka' cultivars (Table 2). Lower TA in 'Eureka' cultivars and 'Villafranca' is in agreement with Batchelor and Bitters (1954). Among all cultivars, 'Foothill Lisbon' ranked among the highest in TSS and TA (Table 2). 'Cook Eureka' had significantly lower TSS and TA than any 'Lisbon' cultivar (Table 2). Since yield, fruit weight, fruit juice content (volume), and acid content are relatively high in 'Foothill Lisbon', total juice and acid production per tree in 'Foothill Lisbon' should also be higher than other cultivars. Juice specific gravity was proportional to TSS in all cultivars (data not shown). 'Foothill Lisbon', 'Prior Lisbon', and 'F.N. Lisbon' had higher percentages of fruit with smooth rind than other cultivars (data not shown), which agrees with previous studies (Hodgson, 1967). All cultivars other than 'Monroe', 'Rosenberger', and 'Prior Lisbon' had fewer than six seeds per fruit, and thus are commercially seedless (Table 2). The differences between our findings and those of Batchelor and Bitters (1954) and Goodall and Bitters (1958) could partially be due to the use of different rootstock, but mainly due to the difference between their coastal climate and our arid low desert conditions.

Relationships between yield and quality. 'Foothill Lisbon', which had the highest cumulative yield (Table 1), also had heavier fruit than other 'Lisbon' cultivars (Table 2). Considering overall yield and fruit quality factors, 'Foothill Lisbon' performed better than other cultivars in our long-term experiment. Although it is difficult to select a single cultivar with all of the desirable characteristics, 'Foothill Lisbon' had high yield, large fruit, and a high percentage of fruit with smooth rind. The combination of desirable yield and quality factors may result in a higher percentage of packout fruit in 'Foothill Lisbon', However, it should be noted that both 'Foothill Lisbon' and 'Monroe
Lisbon' bud sources currently available in Arizona carry the exocortis viroid, which can be transmitted by budding and pruning tools (Calavan, 1959; Garnsey and Jones, 1967). Susceptible rootstock, such as trifoliate orange [Poncirus trifoliata (L.) Raf.], citrange (P. trifoliata $\times$ C. sinensis), and Rangpur lime (C. reticulata var. austera Swing.) must be avoided if budwood tests positive for exorcortis.

Based on this experiment, 'Cook Eureka', 'F.N. Eureka', and 'Villafranca', in spite of thornlessness of trees, had low TA and yield too poorly for planting at the $8.5 \times 9.1-\mathrm{m}$ spacing in the arid climate and sandy soil conditions of southwest Arizona. 'Villafranca' and 'Eureka' cultivars did not differ from 'Lisbon' in cumulative yield efficiency and were better than 'Lisbon' cultivars in 1982 yield efficiency (Table 1). Therefore, 'Villafranca' and 'Eureka' cultivars could have equal or better yield potential if planted at a higher density. However, these cultivars with macrophylla rootstock should be avoided due to the susceptibility to sieve tube necrosis decline.

\section{Literature Cited}

Allen, R. M., D.R. Rodney, and H.H. McDonald. 1976. Sieve tube necrosis of lemon scion and their rootstock. Citrus Rpt. Univ. of Ariz., College of Agr. Ser. P-38. p. 34-37.

Allen, R. M., E.L. Nigh, D.R. Rodney, and H. Schneider. 1982. Macrophylla rootstock necrosis affects more trees in Arizona. Citrograph. 67:133-134.

Allen, R. M., D.R. Rodney, and H.H. McDonald. 1977. Sieve tube necrosis in Arizona. Citrograph. 6:79-80.

Arizona Agricultural Statistics for 1986-1987. Arizona Agricultural Statistics Service. 1987. Bul. S-22:8.

Batchelor, L.D. and W.P. Bitters. 1954. Juice and citric acid content of three California lemon varieties. Calif. Citrograph. 39:187.

Calavan, E.C. and L.G. Weathers. 1959. The distribution of exocortis virus in California citrus, p. 151-154. In: J.M. Wallace (cd.). Citrus virus diseases. Univ. of Calif. Div. Agr. Sci. Berkeley.

Garnsey, S.M, and J.W. Jones. 1967. Mechanical transmission of exorcortis virus with contaminated budding tools. Plant Dis. Rptr. 51:410-413.

Goodall, G.E. and W.P. Bitters. 1958. Lemon fruit quality study in Santa Barbara Co. Citrograph. 43:192.

Hodgson, R.W. 1967. Horticultural varieties of citrus, p. 431-588. In: W. Reuther, H.J. Webber, and L.D. Batchelor (eds.). The citrus industry. vol. 1. Univ. of Calif. Press, Berkeley.

Jahn, O.L. 1979. Penetration of photosynthetically active radiation as a measurement of canopy density of citrus trees. J. Amer. Sot. Hort. Sci. 104:557-560.

Morse, J.G. and C.A. Robertson. 1987. Calculating canopy area of citrus trees and surface area of fruits. Florida Entomol. 70:168-171.

Platt, R. G., R.M. Burns, and H. Schneider. 1972. Necrotic sieve tubes don't make good lemon trees. Citrograph. 57:251-252.

Rouse, A.H. and L.C. Knorr. 1970. Evaluation of pectins from Florida lemons harvested from young trees. Proc. Fla. State Hort. Sot. 83:281-284.

Serfontein, C.M. and H.D. Catling. 1968. Determining the canopy area of citrus trees. South Africa Citrus J. 413:14-15.

Sinclair, W.B. and D.M. Eny. 1945. The organic acid of lemon fruit. Bet. Gaz. 107(2):231-242.

Soni, S.L. and G.S. Randhawa. 1969. Morphological and chemical changes in the developing fruits of lemons (C. limon Burm, f.). Indian J. Agr. Sci. 39:813-829.

Turrell, F.M. 1946. Tables of surfaces and volumes of spheres and of prelates and oblate spheroids, and spheroidal coefficient. Univ. of Calif. Press, Berkeley.

Turrell, F.M. 1961. Growth and photosynthesis area of citrus. Bet. Gaz. 122:284-298. 